\title{
Analysis of Sharia Financing Potentials on Fisheries Sector
}

\author{
Muhfiatun \\ Universitas Islam Negeri Sunan Kalijaga Indonesia \\ muhfiatunassany@gmail.com
}

\begin{abstract}
The purpose of this research is to find out the potency of sharia financing in the fisheries sector in Jetis Village, Nusawungu, Cilacap District. The study was conducted in Jetis Village, Nusawungu, Cilacap District, with the consideration that Jetis Village is the village with the most businesses in the field of fisheries. The sample in this research is fisherman and businessman processed Lea Fish Chips (Krispi Ikan Lea). The data in this research is collected with interview technique. The data analysis used in this research is qualitative and quantitative analysis. The qualitative analysis is used to get an overview of descriptive explanation regarding the fisheries industries. Meanwhile, the quantitative analysis is used for analyzing the cost of every activity, such as investment cost, operational cost, production and marketing cost. Financial analysis is also used to measure cash flow, Break Event Point, Payback Period, Net Present Value and sensitivity analysis. The finding of this research shows that the fisheries business in Jetis Village has the potency to get financing from Islamic Banking. Based on the analysis of the financial feasibility of the lea crispy sich (Krispi Ikan Lea) business is feasible to be cultivated. With a five year project period and 20,6\% of margin rates, this business could pay their payment to the Islamic Bank dan produce a good amount of profit for their business. The fishermen also passed the financial feasibility test and are also cultivated with a five-year period of the project and with a total profit of $R p$ $121,245,775$.
\end{abstract}

Keywords: Sharia Financing Potencials, Financial Feasibility

\section{A. INTRODUCTION}

One of the critical questions often asked for Islamic banking is the validity of sharia due to the determination of product prices which are believed to still refer to the interest rate. The answer to this critical question is of course very important to obtain, considering that the answer is a substantial element in the development of Islamic finance applications, especially the banking sector. If indeed usury/interest should not be a benchmark for product prices, what variables are used as references?

With the absence of usury, the profit of a relative business will only come from productive economic activities, both from trading, leasing or services. Investment activities 
also provide benefits in the form of profit sharing but the profit sharing depends on its main activities, namely buying and selling, leasing or services. Therefore, Islamic financial or banking products should also refer to business activities based on buying, leasing, services, and investment.

Pricing of Islamic bank products should refer to the level of general profits that exist in productive business activities, so specifically, the price of financing products for the Islamic banking property sector is based on the level of general profit in the property sector, as well as other sectors. This, of course, takes into account other factors such as geographical area and operational costs. In short, Islamic banking requires a referral or reference rate form an accurate index of the real sector which reflects the level of profit from the real economic sectors.

So, if the real sector index is available accurately based on sectoral, sub-sector or commodity, and also known for its geographical distribution, this index will certainly provide rich information, not only useful for private businesses but also useful for the government, from the central government to with the area. If the reference rate is fully available, then the question is what benefits can Islamic banking get? With the complete reference rate, Islamic banks are able to more accurately assess real sector projects and which areas are more profitable, understand the characteristics and distribution of risks in various sectors, subsectors, and commodities or even the risks in geographical distribution.

In Arif Sulfiantono's article entitled Sharia Financing Potential 2 (two) Potential AgriBusiness Commodities in the Special Region of Yogyakarta, shows that cultivating ear mushrooms and other mushrooms remain profitable even in unfavorable economic conditions, such as $10 \%$ inflation (Sulfiantoro, 2008). The results of this study provide information on reference rates in the agricultural sector in Yogyakarta. Meanwhile, Muhammad Hakim in his article entitled Property and Potential Business for the Yogyakarta Branch of BTN Sharia concluded that the property business has strategic potential because it is able to absorb a very large workforce as well as prospective because the need for housing continues to increase. It is clear that property businesses have very promising potential both on a national and local scale.

The reference rate for the agricultural sector and the property sector already exists. However, the refreshing rate of the two sectors is not enough, because there are still many sectors that have no reference rate as in the fisheries sector. The fisheries sector that will be 
Analysis of Sharia Financing Potentials on Fisheries Sector

the object of this research is fisheries business in Jetis Village, Nusawungu District, Cilacap Regency. One of the villages that contributes the most fishery products in Cilacap is Jetis Village. The population of Jetis Village is 8,368 people, the number of people who work as fishermen is 700 people (Hakim, 2008). Fish is a product that is produced in Jetis Village. But fish is also a food ingredient that quickly undergoes decay due to high water content. That is why people have always tried to preserve fish so they can be used for a longer time. The process of preserving and processing fish is an important part of the fishing industry chain.

This food has become a public favorite because of its delicious, tasty, and light taste. Processing of fishery products in addition to increasing durability also increases added value. Fisheries business is an activity carried out with a fishery business system which includes preproduction, production, processing, and marketing. This study provides limitations on capture fisheries and processed fish products. Capture fisheries are fisheries businesses based on fishing activities on the high seas (Indian Ocean). Processed fish products that are the object of this research are Krispi Ikan Lea Mak Sinah. Based on the above explanation, it is clear that fisheries business has good potential, therefore Islamic banks should establish mutually beneficial cooperation with the business sector. To measure the potential of Islamic financing in Jetis Village, financial feasibility analysis is used which includes: cash flow analysis, break-even points, payback period, net present value, and sensitivity analysis.

\section{A.1. Sharia Financing}

Financing based on sharia principles is defined as:

"The provision of money or bills that can be equated with it, based on the agreement or loan agreement between Islamic banks and the financed party to return the money or bill after a certain period of time with a reward or profit sharing (Karim, 2016)"

The basic principles of Islamic finance are: a) Justice, mutually beneficial financing both those who use funds and those who provide funds; b) Trust, is the basis for determining financing agreements as well as in calculating profit margins and profit sharing that accompany the financing. These are the types of financing product in Islamic Bank: 


\section{a. Mudharabah}

Financing with a mudharabah contract is a contract of business cooperation between Islamic banks with the owner of funds (Shohibul Maal) with the customer as the fund manager (Mudharib), to conduct business activities with a sharing ratio of the results of an agreement in advance (Mauludi, 2015).

\section{b. Musyarakah}

Musyarakah financing is the investment of funds from shohibul mal (capital owners) to mix their funds / capital in a particular business, with various profits based on the previously agreed ratio. Whereas the loss is borne by all shohibul maal based on their respective funds/ capital (Bank Indonesia).

\section{c. Murabahah}

Murabahah financing is a sale and purchase agreement between the bank and the customer where the Islamic bank buys the items needed by the customer and then sells it to the customer at the acquisition price plus the margin / profit agreed between the Islamic bank and the customer.

d. Salam

Salam financing is an agreement to buy and sell goods by ordering with certain conditions and paying the price first.

e. Ijarah

Ijarah financing is a lease agreement for an item within a certain time through lease payments.

\section{f. Istishna}

Istishna financing is a sale and purchase agreement in the form of ordering goods with certain criteria and requirements agreed between the buyer and seller (Muhammad, 2005).

\section{A.2. Sharia Financing Potency}

In contrast to conventional financing that only knows one type of product, namely financing with interest rate calculation system, Islamic finance has a variety of financing product patterns and flexible profit calculations. Meanwhile, to calculate the profit that is expected to be able to use the margin system or profit sharing ratio. The margin is the difference between the purchase price and the selling price as the expected profit. The profit 
Analysis of Sharia Financing Potentials on Fisheries Sector

sharing ratio is the proportion of the expected profit from a business. In the calculation of profit sharing ratio can use the method for profit and loss (profit and loss sharing) or the method for revenue (revenue sharing).

Profit sharing gains and/or losses that may arise from business activities are borne together. Profit sharing, the profit sharing ratio is calculated after deducting all costs (net profit). While revenue sharing is calculated based on operating income before deducting operating costs. The diversity of Islamic financing products and the calculation of profit levels can provide flexibility for both the customer and the Sharia Bank in choosing financing products that are in accordance with their respective capabilities and capacities.

The provision of loans/financing for customers is based on the principle of profit sharing, buying and selling, or buying leases that are free from interest stipulation and provide a sense of security because what is given to customers is non-cash goods and there is no interest expense determined in advance. Conceptually, the prospect of sharia banking to support financing for fisheries is still very open. This can be seen from two perspectives, namely the potential amount of funds and assets owned by Islamic banks and the good potential of fisheries business in Jetis Village. Besides having large funds, banks also have advantages over other financing institutions: 1). Loan ceiling is greater than other financing institutions; 2). Have clear legal power; 3). Can serve capital needs for all types of businesses and layers of society provided they are considered feasible; 5). Have a strict reward and punishment system that can encourage people to act more professionally in trying (Numanaf, 2006).

\section{A.3. Financial Feasibility of Fisheries Business}

The financial feasibility analysis is used to find out whether fisheries business is feasible or not by using investment feasibility criteria: break-even point analysis, cash flow analysis, payback period analysis, NPV analysis, and sensitivity analysis.

a. BEP Analysis is a method or technique used by a company officer/manager to find out what volume (amount) of sales and volume of production the company does not profit (Sigit, 2007).

b. One very important financial analysis is cash flow. Financing for production units of goods and services is provided in large quantities and the deposition is long enough. 
Journal of Finance and Islamic Banking | Vol. 1 No. 2, July-December 2018

c. The NPV method is a classic investment valuation method that is the most popular to date. The principle of NPV is to calculate the cash flows that will be received in the future at the present value. Investment projects are said to be profitable if the present value of net cash flows is greater than the present value of the investment. In short, NPV is the difference between the present value of benefits and the present value of costs.

d. Payback period is used to estimate the length of time needed by the project to return the investment and working capital invested.

e. Sensitivity Analysis. In the feasibility analysis of a project, production / operational costs and income will usually be used as a benchmark in measuring business feasibility because these two things are core components in a business activity, moreover that the components of operating costs and income are also based on assumptions and projections so that they have a level of uncertainty which is quite high. To reduce this risk, a sensitivity analysis is needed which is used to test the level of project sensitivity to changes in input and output prices (Bank Indonesia, 2005).

\section{B. DATA AND METHOD}

The study was conducted in Jetis Village, Nusawungu District, Cilacap District, with the consideration that Jetis Village is the village with the most businesses in the field of fisheries. The population in this study were fisheries entrepreneurs in Jetis Village. The sample determination method used in this study is the determination of the sample taken intentionally (purposive) on the capture fisheries businessmen (fishermen) and fish processing business actors (fish krispi lea) in Jetis Village.

This research was conducted in September-October 2017. Analysis of the data used is quantitative analysis and qualitative analysis. Qualitative analysis is used to obtain a description or descriptive of fisheries business and quantitative analysis is carried out to analyze the costs incurred during activities ranging from investment costs, operations, production to marketing. 
Analysis of Sharia Financing Potentials on Fisheries Sector

\section{RESULT AND DISCUSSION}

\section{C.1. Sharia Financing Potency}

Business potential in the maritime and fisheries sector is very large, this can be seen in the many potential fisheries that have not been explored properly. Many business actors are constrained by capital, technology, and other major supporting facilities that are not yet available, so that the business development process of the fisheries sector has not achieved optimal results, namely increasing the income and welfare of business actors. Islamic banking has a great potential to provide financing in the fisheries sector. Islamic banking has many different financing models. Whereas to calculate the profit that is expected to be able to use the margin system or profit sharing ratio.

Profit sharing ratio is used in financing with the principle of cooperation. Business potential in the maritime and fisheries sector is very large, this can be seen in the many potential fisheries that have not been explored properly. Many business actors are constrained by capital, technology, and other major supporting facilities that are not yet available, so that the business development process of the fisheries sector has not achieved optimal results, namely increasing the income and welfare of business actors. Islamic banking has a great potential to provide financing in the fisheries sector. Islamic banking has many different financing models. Whereas to calculate the profit that is expected to be able to use the margin system or profit sharing ratio.

Profit sharing ratio is used in financing with the principle of cooperation. Referring to the Islamic financial system that has a wide variety of financing products, the financial aspects will be presented for financing murabahah (sale-purchase) methods for investment financing and for working capital financing. The consideration is because this murabahah product has been widely applied by Islamic banking and the user community has already recognized and accessed the financing pattern.

Murabahah products are also an effort to mitigate risks for both businesses and customers because in this financing product the margin is definitely determined at the beginning of the contract. Murabahah financing also gives choices to Islamic banks and customers whether financing will be used to finance all business components or only for certain components. Islamic banks can provide murabahah financing to fishermen to purchase 


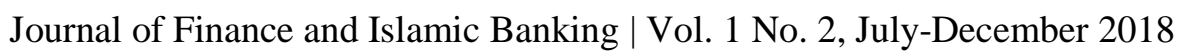

fishing equipment (ships, outboard engines, etc.), while for Islamic banks fish processing businesses can provide murabahah financing for the purchase of production equipment.

\section{C.2. Financial Feasibility Analysis}

\section{a. The Cost of Fisheris Business}

Investment costs are fixed costs whose amount is not affected by the number of products produced. While operating costs are variable costs whose size is affected by the amount of production. Total costs are all costs incurred to produce a product. The total cost incurred by fishermen to catch fish for one year is Rp 158,474,225; in one year fishermen go fishing for 120 times. the total cost incurred by the producer of lea fish krispi for one year was Rp. 142,477,000; in one year the producer of fish krispi lea carried out 104 production times.

\section{b. Business Revenue}

Acceptance is the value of the total product produced or is the result of multiplication between physical production and the selling price, in this case, the multiplication between the production of fish krispi lea with the selling price, and the multiplication between fishermen's results goes to sea with the selling price. The average amount of production obtained by producers in one year of production is $2,400 \mathrm{~kg}$ and the average selling price of $\mathrm{Rp} 75,000 / \mathrm{kg}$ in one year can be 104 times the production. The average fisherman goes to sea in one year is 120 times. With the average result of fishing for Rp. 279,720,000.

\section{c. Business Benefits}

The profit obtained by the fish krispi lea producer is the difference between the revenue and the total cost incurred by the producer of fish krispi lea. The profit of the fish krispi lea business is Rp. 37,253,000; in one year. While the benefits obtained by fishermen are the difference between revenue and the total costs incurred to catch fish in the sea. Fishermen's advantage is Rp. 121,245,775; in one year.

\section{d. Financial Feasibility Analysis}

Based on the results of the calculation of the financial feasibility analysis of the fish krispi lea processing business, the values for the business feasibility criteria are obtained. 
Analysis of Sharia Financing Potentials on Fisheries Sector

Table 1. Business Feasibility Criteria for

Processing Lea Krispi Fish in Jetis Village

\begin{tabular}{|c|c|c|}
\hline No & Eligibility Criteria & Value \\
\hline 1 & Net Present Value (NPV) & Rp $351,600,310$ \\
\hline 2 & Payback Period $(\mathrm{PbP})$ & 4 years \\
\hline \multicolumn{3}{|c|}{ Source: Primary Data Processing in 2017} \\
\hline \multicolumn{3}{|c|}{$\begin{array}{l}\text { Table 2. Financial Feasibility Criteria for } \\
\text { Offshore Sea Fishing (Fishermen) Business in Jetis Village }\end{array}$} \\
\hline No & Eligibility Criteria & Value \\
\hline 1 & Net Present Value (NPV) & $\operatorname{Rp} 962,961,209$ \\
\hline 2 & Payback Period (PbP) & 1,3 years \\
\hline
\end{tabular}

Source: Primary Data Processing in 2017

e. Sensivity Analysis

1. Analysis of Sensitivity of Catching Offshore Fisheries (fishermen)

The sensitivity analysis that is used is the switching value analysis which shows that the fisherman's business still achieves profit with changes in raw material prices and a decrease in selling prices. Sensitivity analysis for capture fish business in the high seas in this study was carried out using parameters (size or benchmark) of $10 \%$ and $20 \%$ increase in fuel prices, $5 \%$ increase in selling prices and 5\% and 10\% sea fishing.

Table 3. Result of Fisheries Business Switching Analysis

\begin{tabular}{|l|c|c|c|r|}
\hline \multicolumn{1}{|c|}{ Parameter } & \multirow{2}{*}{ N } & \multicolumn{3}{c|}{ Investment Criteria } \\
\cline { 3 - 5 } & & Profit (Rp) & NPV (Rp) & PbP (years) \\
\hline BBM Up & $10 \%$ & $110,445,775$ & $1,296,341,209$ & 1.5 \\
\hline BBM Up & $20 \%$ & $99,645,775$ & $1,142,225,209$ & 1.8 \\
\hline Price Up & $5 \%$ & $297,231,775$ & $3,785,791,429$ & 0.5 \\
\hline Price Down & $5 \%$ & $107,499,775$ & $1,268,047,789$ & 1.5 \\
\hline Price Down & $10 \%$ & $93,273,775$ & $1,079,268,769$ & 1.7 \\
\hline
\end{tabular}

Source: Primary Data Processing in 2017 


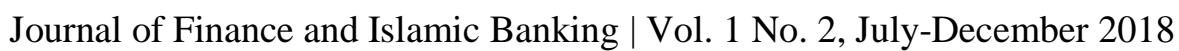

Sensitivity analysis with fuel oil (Bahan Bakar Minyak/BBM) parameters up 10\% produces a positive NPV value of 1,296,341,209; profit of $\mathrm{Rp} 110,445,775$; and the payback period is 1.5 years or 18 months. In BBM, 20\% increased by Rp 99,645,775, positive NPV 1,142,225,209; and the payback period is 1.8 years or 21 months. If the price parameter results go up by $5 \%$ then the profit obtained is Rp. 297,231,775; the payback period is 0.5 years or 6 months, the NPV is positive at 3,785,791,429. Sensitivity analysis with price parameters of sea fishing fell 5\% indicating that a 5\% price reduction yielded a profit of Rp 107,499,775; Positive NPV of 1,268,047,789; and the payback period is 1.4 years. On the decline in selling price the result of fishing at $10 \%$ resulted in a positive NPV of 1,079,268,769; profit of Rp 93,273,775; and the payback period for 1.6 years.

From the results of the sensitivity analysis, it was shown that the decrease in selling prices had a greater effect, this could be seen from the profit and the smaller NPV value compared to the increase in fuel prices. In addition, a decrease in production volume or selling price is more sensitive or sensitive compared to the increase in fuel prices. The maximum limit of change greatly affects whether or not the business is feasible. The greater the percentage obtained, the business is not or less sensitive to the changes that occur. It can be proved that when the fuel used in the fishing business experienced a price increase of up to 2 times (10\% \& 20\%), the fishermen were still able to operate and could cover production costs.

\section{Sensitivity Analysis of Krispi Ikan Lea}

Sensitivity analysis of fish leach crispy business in this study was carried out using parameters (size or benchmark) of $10 \%$ and $15 \%$ increase in raw materials, $10 \%$ increase in product selling prices and a $5 \%$ decrease in product selling prices. 
Analysis of Sharia Financing Potentials on Fisheries Sector

Table 4. The Result of Krispi Ikan Lea Switching Value Analysis

\begin{tabular}{|l|c|l|c|l|r|}
\hline \multirow{2}{*}{ Parameter } & $\%$ & \multicolumn{3}{|c|}{ Invesment Criteria } \\
\cline { 3 - 6 } & $10 \%$ & $30,909,000$ & $149,091,000$ & $\begin{array}{l}80 \mathrm{x} \\
\text { production }\end{array}$ & PbP (years) \\
\hline $\begin{array}{l}\text { Raw } \\
\text { Material }\end{array}$ & $15 \%$ & $27,737,000$ & $215,806,990$ & $\begin{array}{l}81 \mathrm{x} \\
\text { production }\end{array}$ & 5.5 \\
\hline $\begin{array}{l}\text { Raw } \\
\text { Material }\end{array}$ & $10 \%$ & $55,253,000$ & $590,460,310$ & $\begin{array}{l}69 \mathrm{x} \\
\text { production }\end{array}$ & 2.6 \\
\hline Price Up & $5 \%$ & $28,853,000$ & $240,132,310$ & $\begin{array}{l}80 \mathrm{x} \\
\text { production }\end{array}$ & 4.9 \\
\hline $\begin{array}{l}\text { Price } \\
\text { Down }\end{array}$ & & & & 5.5 \\
\hline
\end{tabular}

Source: Primary Data Processing in 2017

Sensitivity analysis with raw material parameters up $10 \%$ resulting in a positive NPV value of 149,091,000; profit of Rp. 30,909,000; and a payback period of 4.8 years. When raw materials increase by $15 \%$ produces losses of Rp. 27,737,000; Positive NPV 215,806,990; and the payback period is 5.4 years. Because $\mathrm{PbP}>$ is from 5 years, when the price of raw materials goes up $15 \%$ this investment is not feasible. If the price parameter of lea fish krispi rises by $10 \%$ then the profit obtained is Rp. 55,253,000; payback period 2.5 years, positive NPV of 590,460,310. Sensitivity analysis with the parameters of fish chrysanthemum prices down $5 \%$ indicates that a $5 \%$ price reduction yields a profit of Rp. 28,853,000; Positive NPV of 240,132,310; and the payback period of 4.9 years.

From the results of the sensitivity analysis carried out shows that the increase in raw material prices has a greater effect, this can be seen from the profit and the smaller NPV value compared to the increase in the decrease in the price of fish krispi lea. The maximum limit of change greatly affects whether or not the business is feasible. The greater the percentage obtained, the business is not or less sensitive to the changes that occur. It can be proved that when the raw materials used in the fishing business experience a price increase of up to 2 times $(10 \% \& 15 \%)$, the fish krispi lea entrepreneurs can still operate and can cover production costs. 
Journal of Finance and Islamic Banking | Vol. 1 No. 2, July-December 2018

\section{CONCLUSION}

From the research results obtained can be concluded as follows:

1. Lea fish krispi business has great potential to be developed for both domestic and overseas consumers.

2. Fish catching business has great potential to be developed for consumers in the jetis village and outside the jetis village.

3. Based on the analysis of financial feasibility, the fish krispi lea business is feasible to be cultivated. With a 5-year project period and a margin rate of $20.6 \%$, this business can pay obligations to Islamic banks and generate sufficient profits for the businessmen.

4. Based on the financial feasibility analysis, capture fisheries are suitable to be cultivated. With a 5-year project period and a profit of $\mathrm{Rp} 121,245,775$; this business can pay liabilities to Islamic banks and generate adequate profits for its entrepreneurs.

5. The results of the sensitivity analysis for the fish krispi lea business show that the increase in the price of raw materials is more sensitive or sensitive when compared to the decrease in the selling price of fish lei krispi.

6. The results of a sensitivity analysis for capture fish businesses indicate that the decline in selling prices of fish catches is more sensitive or sensitive compared to the increase in fuel prices.

\section{Reference}

Ahmad, Dadang. 2000. Methodologi Penelitian Agama, Perpektif Ilmu Perbandingan Agama. Bandung: Pustaka Setia,.

Anonim. 2005. Pola Pembiayaan Usaha Kecil, Usaha Budidaya Paprika. Bank Indonesia, Tidak dipublikasikan.

Antonio, M. syafi'i. Bank Syariah: dari Teori ke Praktik. Jakarta: Gema Insani Press.

Arikunto, Suharsimi. 1993. Prosedur Penelitiaan: Suatu Pendekatan Praktik. Jakarta: Rienika Cipta.

Badan Penelitian dan Pengembangan Pertanian. 2006. Sosial Ekonomi dan Kebijakan Pertanian.

Bank Indonesia. Pola Pembiayaan Usaha Kecil Syariah (PPUK Syariah). Usaha Kerupuk Ikan. 
Analysis of Sharia Financing Potentials on Fisheries Sector

Fahmi, Irham. 2016. Teori dan Teknik Pengambilan Keputusan: Kualitatif dan Kuantitatif. Jakarta: Raja Grafindo Persada.

Hadi, Sutrisno. 1989. Metodologi Reseach. Yogyakarta: Andi Offset.

Hakim, Muhammad. 2008. Usaha Properti dan Potensinya Bagi BTN Syariah Cabang Yogyakarta. Tesis Universitas Islam Negeri Sunan Kalijaga Yogyakarta.

Hasan, Iqbal. 2005. Pokok-Pokok Materi Statistik 2. Jakarta: Bumi Aksara.

Karim, Adiwarman. 2016. Bank Islam: Analisis Fiqih dan Keuangan. Jakarta: Rajagrafindo Persada.

Kountur, Ronny. 2007. Metode Penelitian: Penyusun Skripsi dan Tesis. Jakarta: Penerbit PPM.

Mauludi AC, Ali. 2015. Akuntansi Pembiayaan Mudharabah. Jurnal Iqtishadia, Vol.2, No.2, Desember 2015.

Muhammad. 2005. Manajemen Pembiayaan Bank Syariah. Yogyakarta: UPP AMP YKPN.

Nawawi, Hadari. 1998. Metode Penelitian Bidang Sosial. Yogyakarta: Gadjah Mada Press.

Numanaf dkk. Analisis Sistem Pembiayaan Mikro dalam Mendukung Usaha Pertanian di Pedesaan. Pusat Analisis.

Patria, Andreas D., dkk. Biaya Transaksi Usaha Perikanan Skala Kecil di Kabupaten Cilacap. Jurnal Sosek KP Vol.9, No.2 Tahun 2014.

Pramudiana, Yudi. 2016. Business Plan. Bandung: PT Remaja Rosdakarya Offset.

Saptana dan Ashari. Prospek Pembiayaan Syariah untuk Sektor Pertanian. Jurnal Forum Penelitian Agro Ekonomi, Volume 23 No:2, Desember 2005.

Sigit, Soehard. 2007. Analisis Break Even, Ancangan Linier Secara Ringkas dan Praktis. Yogyakarta: BPFE.

Sugiyono,. 2010. Metode Penelitian Usaha. Bandung: Alfabeta.

Sulfiantono, Arif. 2008. Potensi Pembiayaan Syariah 2 (Dua) Komoditas Agriusaha Potensial di Daerah Istimewa Yogyakarta. Tesis Universitas Islam Negeri Sunan Kalijaga Yogyakarta.

Soehada, M. 2003. Pengantar Matodologi Penelitian Sosial Kualitatif . Yogyakarta.

Sutrisno,. 2013. Manajemen Keuangan: Teori Konsep \& Aplikasi. Yogyakarta: Ekonisia.

Usman, Husaini, Purnomo Setiady Akbar. 1996. Metode Penelitian Sosial. Jakarta: Bumi Aksara.

Walizer, M. 1978. Metode dan Analisis Penelitiaan. Jakarta: Erlangga. 


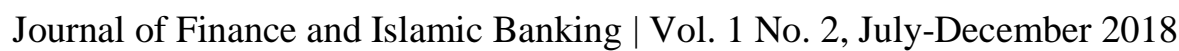

Winarti, Lili. 2016. Analisis Sensitivitas Usaha Pengolahan Kerupuk Ikan Pipih di Kecamatan Seruyan Hilir Kabupaten Seruyan. Jurnal Zira'ah, Vol 41, No 2, Juni 2016.

Yahya, Muchlis \& Edy Yusuf Agunggunanto. 2011. Teori Bagi Hasil (Profit And Loss Sharing) dan Perbankan Syariah dalam Ekonomi Syariah. Jurnal Dinamika Ekonomi Pembangunan, Juli 2011, Volume 1, No 1. 